\title{
Effects of annealing and thermo-mechanical treatment on the microstructures and mechanical properties of a carbon-doped FeNiMnAl multi-component alloy
}

\author{
Zhangwei Wang, Ian Baker \\ Thayer School of Engineering, Dartmouth College, 14 Engineering Drive, Hanover, NH 03755, USA
}

\section{A R T I C L E I N F O}

\section{Keywords:}

Multi-component alloy

Microstructure

Mechanical properties

Strengthening mechanisms

Microbands

\begin{abstract}
A B S T R A C T
The microstructures and mechanical properties of both undoped and carbon-doped (1.26 at\%) f.c.c./B2 $\mathrm{Fe}_{36} \mathrm{Ni}_{18} \mathrm{Mn}_{33} \mathrm{Al}_{13}$ multi-component alloys have been investigated in the as-cast, annealed and recrystallized states. A lamellar structure is present in the undoped alloy, while a tetragonal martensite with irregular shape is present in the carbon-doped alloy. B2-structured precipitates form upon annealing in both alloys, whose size and volume fraction increases with increasing annealing time. Lamellar coarsening also occurs during annealing of the undoped alloy. Two different thermo-mechanical treatments were applied to the carbon-doped alloy in order to decrease the grain size and disperse the martensite, which produced a significant increase in strength. The changes in yield strength are discussed in terms of the underlying strengthening mechanisms, i.e., phase boundary strengthening, grain boundary strengthening, interstitial strengthening, and precipitation strengthening. The carbon addition results in a sharp increase in ductility of the as-cast alloy, a feature ascribed to microband formation during the tensile test arising from the increase of lattice friction stress. Similar to some single-phase f.c.c. alloys, microband-induced plasticity (MBIP) effect is found to present in a two-phase multicomponent alloy in this study.
\end{abstract}

\section{Introduction}

A novel f.c.c./B2 dual-phase $\mathrm{Fe}_{36} \mathrm{Ni}_{18} \mathrm{Mn}_{33} \mathrm{Al}_{13}$ (in at\%) multi-component alloy, which was designed based on earlier studies of lamellar FeNiMnAl alloys [1-6], exhibits an excellent combination of strength and ductility, suggesting promising applications for structural materials [7]. It is well established that the lamellar spacing plays a critical role in the strength of lamellar-structure alloys, as shown in TiAl alloys [8,9], Ni-Fe-Al alloys [10-12], and pearlitic steels [13,14]. Our earlier work [15] revealed that the addition of up to 6 at\% $\mathrm{Ti}$ to $\mathrm{Fe}_{36} \mathrm{Ni}_{18} \mathrm{Mn}_{33} \mathrm{Al}_{13}$ leads to a substantial reduction in lamellar spacing from $1560 \mathrm{~nm}$ to $155 \mathrm{~nm}$ and thus, produces a sharp increase in yield strength from $270 \mathrm{MPa}$ to $953 \mathrm{MPa}$, albeit with a reduction in the elongation to failure from $22.8 \%$ to $2.3 \%$.

The introduction of precipitates offers a potential strengthening route [16]. For example, Hanna et al. [17] showed that the yield strength of a spinodally-formed B2/b.c.c. $\mathrm{Fe}_{30} \mathrm{Ni}_{20} \mathrm{Mn}_{25} \mathrm{Al}_{25}$ increased from $1510 \mathrm{MPa}$ to $2350 \mathrm{MPa}$ after annealing at $823 \mathrm{~K}$ for $115 \mathrm{~h}$ due to the strengthening from $\beta$-Mn precipitates. Similarly, He et al. [18] produced coherent nano-sized $\mathrm{L}_{2}$ precipitates in f.c.c. $(\mathrm{FeCoNiCr})_{94} \mathrm{Ti}_{2} \mathrm{Al}_{4}$ after thermo-mechanical treatment, resulting in a yield strength of over $1 \mathrm{GPa}$.
Grain size reduction is another strengthening route. In dual-phase multicomponent alloys, grain growth of the matrix phase can be hindered by second phase pinning, leading to the formation of alloys with a very fine grain size. Baker et al. [19] cold rolled a f.c.c./B2 $\mathrm{Fe}_{28.2} \mathrm{Ni}_{18.8} \mathrm{Mn}_{32.9} \mathrm{Al}_{14.1} \mathrm{Cr}_{6}$ alloy to $\sim 65 \%$ reduction in thickness, followed by an annealing at $1273 \mathrm{~K}$, which produced a dual-phase alloy with a grain size of $0.5 \mu \mathrm{m}$. Wani et al. [20] developed a duplex $\mathrm{L}_{2} / \mathrm{B} 2 \mathrm{AlCoCrFeNi} 2_{2.1}$ alloy with fine equi-axed grains $(\sim 0.60 \mu \mathrm{m})$ after cold-rolling and annealing, which showed an high ultimate tensile strength of $\sim 1.2 \mathrm{GPa}$ due to the combination of grain boundary strengthening and strengthening from the $\mathrm{B} 2$ phase.

In addition to the above strengthening mechanisms, carbon has been added to produce interstitial strengthening in multicomponent alloys [21-23]. Wu et al. [21] showed that 0.5 at\% carbon addition to a single f.c.c. $\mathrm{CoCrFeMnAl}$ alloy increased the room-temperature yield strength from $165 \mathrm{MPa}$ to $225 \mathrm{MPa}$ but with a reduction in elongation from $65 \%$ to $38 \%$. Wang et al. [23,24] found that adding up to 1.1 at $\%$ carbon to a single f.c.c. $\mathrm{Fe}_{40.4} \mathrm{Ni}_{11.3} \mathrm{Mn}_{34.8} \mathrm{Al}_{7.5} \mathrm{Cr}_{6}$ alloy increased both the yield strength (from $159 \mathrm{MPa}$ to $355 \mathrm{MPa}$ ) and elongation to failure (from $41 \%$ to $50 \%$ ), since the carbon solute induced the formation of

\footnotetext{
* Corresponding author.

E-mail address: Ian.Baker@dartmouth.edu (I. Baker).
} 

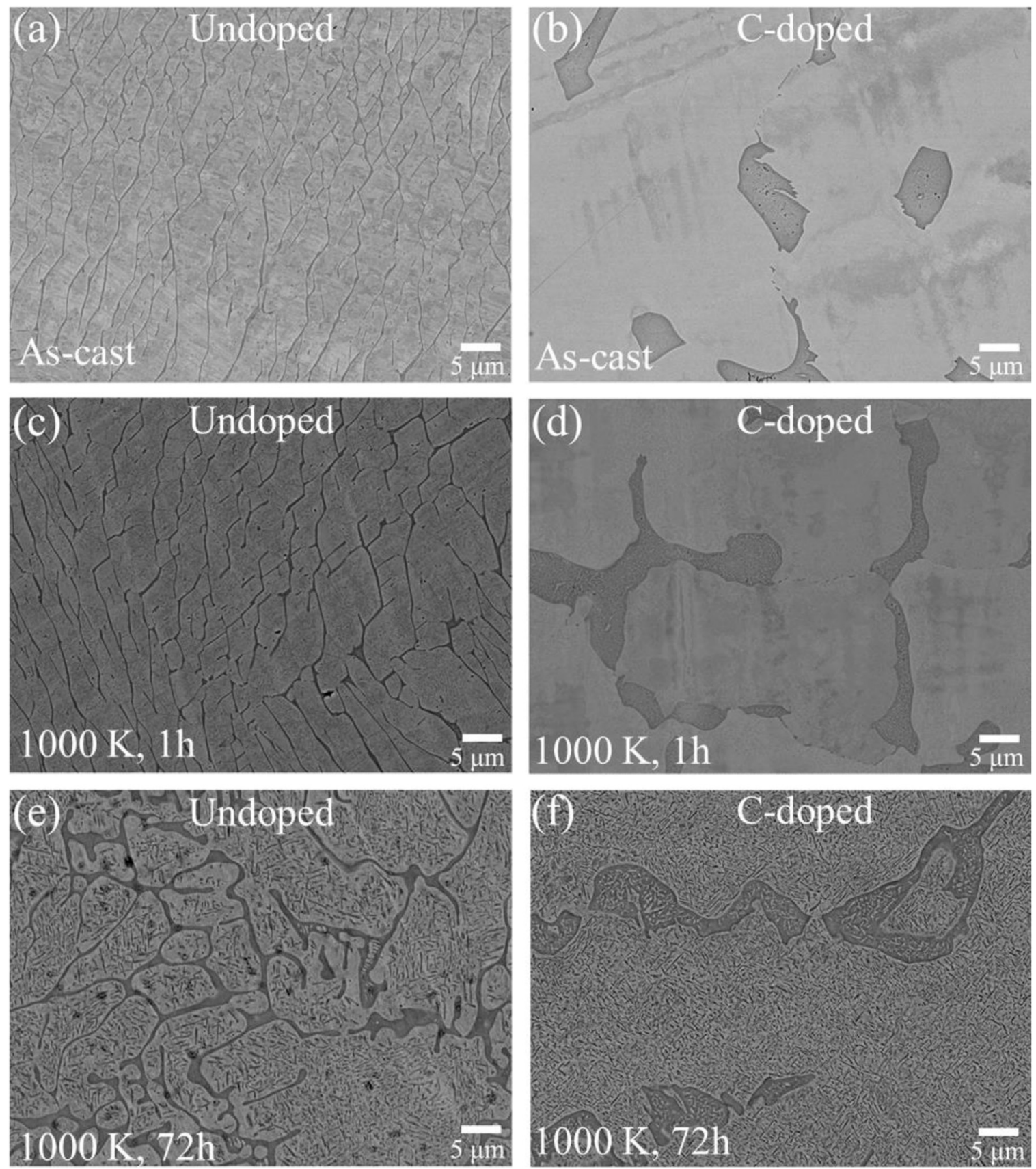

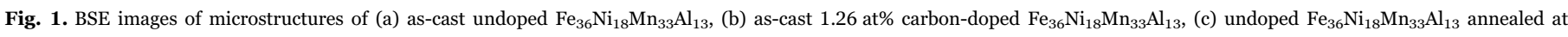

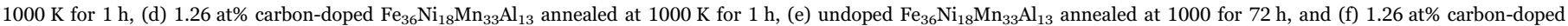
$\mathrm{Fe}_{36} \mathrm{Ni}_{18} \mathrm{Mn}_{33} \mathrm{Al}_{13}$ annealed at $1000 \mathrm{~K}$ for $72 \mathrm{~h}$.

microbands. Thus, carbon was added to achieve interstitial strengthening in the two-phase alloy $\mathrm{Fe}_{36} \mathrm{Ni}_{18} \mathrm{Mn}_{33} \mathrm{Al}_{13}$ in this study. Annealing and thermo-mechanical treatments were also conducted in attempts to strengthen both undoped and carbon-doped $\mathrm{Fe}_{36} \mathrm{Ni}_{18} \mathrm{Mn}_{33} \mathrm{Al}_{13}$ alloys. The microstructural evolution of the microstructures of alloys was investigated to reveal the underlying strengthening mechanisms. The dislocation substructures after fracture were examined to clarify the effect of carbon on the deformation behavior of the alloys.

\section{Experimental}

Arc-melting was used to produce ingots of undoped and carbondoped $\mathrm{Fe}_{36} \mathrm{Ni}_{18} \mathrm{Mn}_{33} \mathrm{Al}_{13}$ alloys from pieces of $99.99 \% \mathrm{Fe}, 99.95 \% \mathrm{Ni}$, 99.9\% $\mathrm{Mn}, 99.9 \% \mathrm{Al}$ and $99 \% \mathrm{Fe}_{3} \mathrm{C}$. Detailed arc-melting procedures can be found elsewhere [15]. The chemistry of the carbon-doped alloy was determined by Chicago Spectro Service Laboratory based on ASTM E1019 and ASTM E1621 method, which showed the carbon content of the alloy is 1.26 at\%. The as-cast alloys were annealed at $1000 \mathrm{~K}$ for either $1 \mathrm{~h}$ or $72 \mathrm{~h}$ in argon atmosphere to protect from oxidation.

Two different thermo-mechanical treatments ( $\mathrm{T} 1$ and $\mathrm{T} 2$ ) were performed on the as-cast carbon-doped alloy to disperse the second phase and refine the grain size.

- T1 thermo-mechanical treatment: specimens were cold-rolled to a $70 \%$ reduction in thickness with a reduction of $\sim 5 \%$ per pass, and then annealed at $1273 \mathrm{~K}$ for $1 \mathrm{~h}$, in order to produce a finer microstructure.

- T2 thermo-mechanical treatment: In order to further disperse the second phase, two thermo-mechanical treatment were performed. An initial cold-rolling of $50 \%$ reduction thickness and 

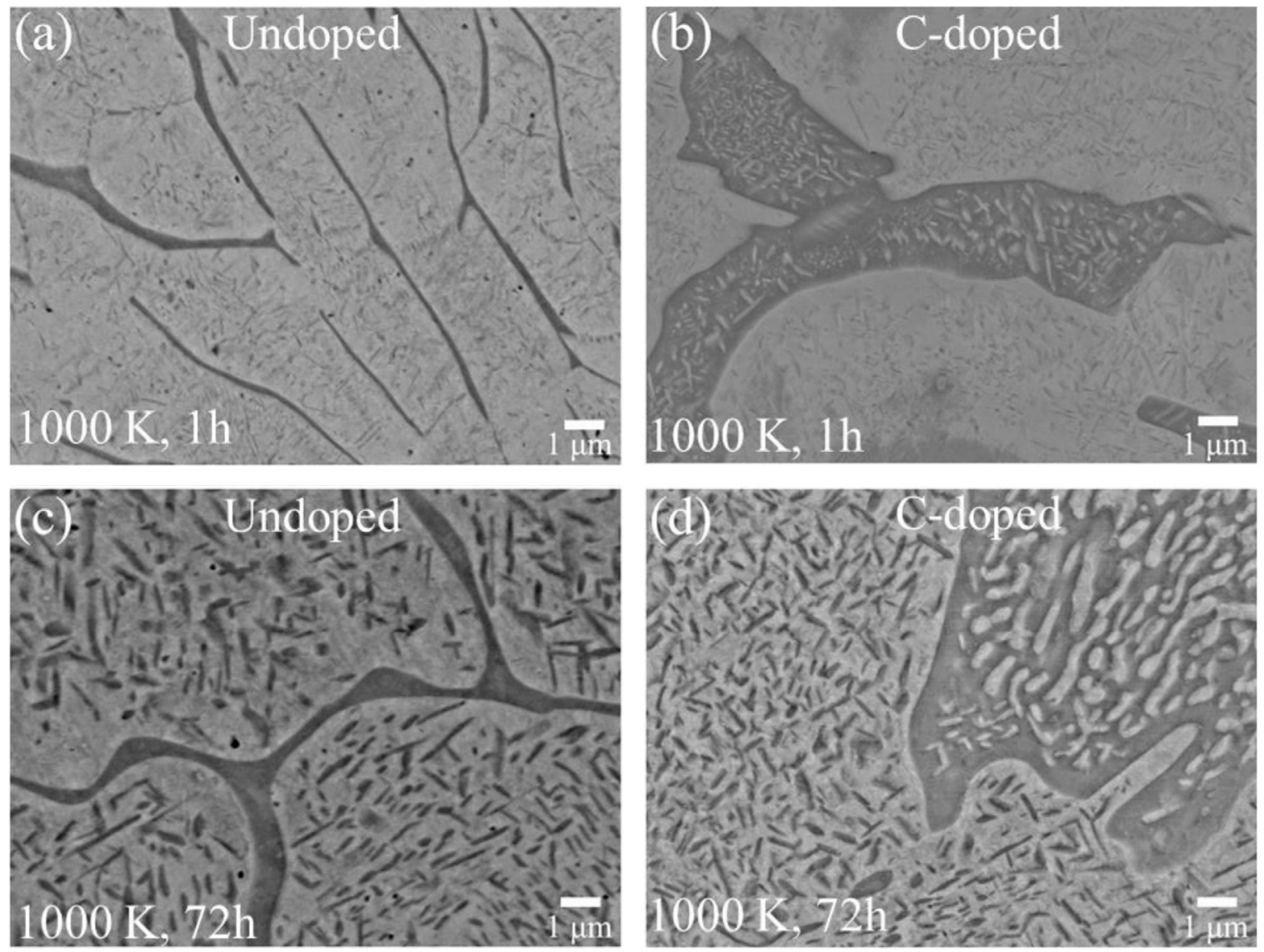

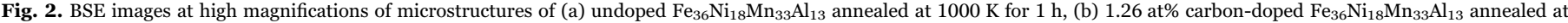
$1000 \mathrm{~K}$ for $1 \mathrm{~h}$, (c) undoped $\mathrm{Fe}_{36} \mathrm{Ni}_{18} \mathrm{Mn}_{33} \mathrm{Al}_{13}$ annealed at 1000 for $72 \mathrm{~h}$, and (d) 1.26 at\% carbon-doped $\mathrm{Fe}_{36} \mathrm{Ni}_{18} \mathrm{Mn}_{33} \mathrm{Al}_{13}$ annealed at $1000 \mathrm{~K}$ for $72 \mathrm{~h}$.

Table 1

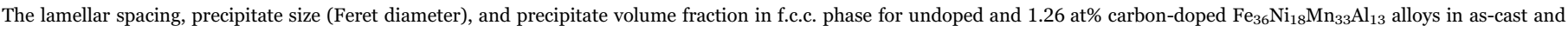
annealed states. The error bars indicate the standard deviation of total measurements.

\begin{tabular}{|c|c|c|c|c|}
\hline Alloy & State & Lamellar spacing $(\mu \mathrm{m})$ & Precipitate size (nm) & Precipitate volume fraction in f.c.c. phase (\%) \\
\hline $\mathrm{Fe}_{36} \mathrm{Ni}_{18} \mathrm{Mn}_{33} \mathrm{Al}_{13}$ & As-cast & $1.6 \pm 0.5$ & - & - \\
\hline $\mathrm{Fe}_{36} \mathrm{Ni}_{18} \mathrm{Mn}_{33} \mathrm{Al}_{13}$ & $1000 \mathrm{~K}, 1 \mathrm{~h}$ & $2.3 \pm 0.5$ & $139 \pm 99$ & $14.9 \pm 0.2$ \\
\hline $\mathrm{Fe}_{36} \mathrm{Ni}_{18} \mathrm{Mn}_{33} \mathrm{Al}_{13}$ & $1000 \mathrm{~K}, 72 \mathrm{~h}$ & $4.2 \pm 0.9$ & $409 \pm 272$ & $41.5 \pm 1.9$ \\
\hline $\mathrm{Fe}_{36} \mathrm{Ni}_{18} \mathrm{Mn}_{33} \mathrm{Al}_{13} \mathrm{C}_{1.26}$ & $1000 \mathrm{~K}, 1 \mathrm{~h}$ & - & $149 \pm 109$ & $14.4 \pm 0.5$ \\
\hline $\mathrm{Fe}_{36} \mathrm{Ni}_{18} \mathrm{Mn}_{33} \mathrm{Al}_{13} \mathrm{C}_{1.26}$ & $1000 \mathrm{~K}, 72 \mathrm{~h}$ & - & $495 \pm 342$ & $46.0 \pm 3.1$ \\
\hline
\end{tabular}

anneal at $1373 \mathrm{~K}$ for $4 \mathrm{~h}$ was followed further cold-rolling to a $50 \%$ reduction in thickness and annealing at $1273 \mathrm{~K}$ for $4 \mathrm{~h}$.

A Rigaku D/MAX 2000 diffractometer with $\mathrm{Cu}-\mathrm{Ka}$ radiation was used to perform X-ray diffraction (XRD) analysis on the alloys. The diffractometer was operated at $40 \mathrm{keV}$ and $300 \mathrm{~mA}$, and step scanning was performed for $2 \theta$ from $20^{\circ}$ to $120^{\circ}$ with a scanning rate of $1^{\circ}$ per min. The lattice parameter of the f.c.c. phase in the as-cast, carbondoped alloy was determined based on the XRD result using an extrapolation method [15].

The microstructures of the alloys in the as-cast, annealed and recrystallized states were examined using both a FEI XL-30 field emission gun (FEG) scanning electron microscope (SEM) in both backscattered electron (BSE) and secondary electron (SE) modes operated at $15 \mathrm{keV}$, and a FEI Tecnai F20 FEG transmission electron microscope (TEM) equipped with energy dispersive X-ray spectrometry (EDS) operated at $200 \mathrm{kV}$. The sample preparation procedures for SEM and TEM are listed in [15]. The crystal spacing (d) of martensite in the as-cast carbon-doped alloy was obtained from $\mathrm{d}=\lambda L / R$, where $\lambda L$ is the camera constant and $\mathrm{R}$ is the distance between the transmitted and diffracted spots. The lattice parameters of the martensite phase were calculated based on the crystal spacing.

The lamellar spacing, size of precipitates and precipitate fraction in the f.c.c. phase were calculated based on analysis of BSE images using Image J. At least 300 measurements for precipitates and 40 measurements for lamellae were performed. The Feret diameter was used to define the particle size of the precipitates. A linear intercept method was used to determine the grain size.

Dog-bone specimens with a gauge length of $10 \mathrm{~mm}$, width of $\sim 2.6 \mathrm{~mm}$ and thickness of $\sim 1.2 \mathrm{~mm}$, polished to mirror surfaces by using $0.3 \mu \mathrm{m}$ alumina powder, were used for tensile tests. Three tensile tests were conducted for each alloy at room temperature with an initial strain rate of $5 \times 10^{-4} \mathrm{~s}^{-1}$. The elongation to fracture was determined from the change of gauge length from the tensile tests. The work-hardening rate at $1 \%$ plastic strain was determined by calculating $d \sigma / d \varepsilon$ at that strain, where $\sigma$ is the flow stress and $\varepsilon$ is the strain. The fracture surfaces were examined in the SEM using SE mode and the dislocation substructures of tensile-fractured specimens were examined in the TEM. 

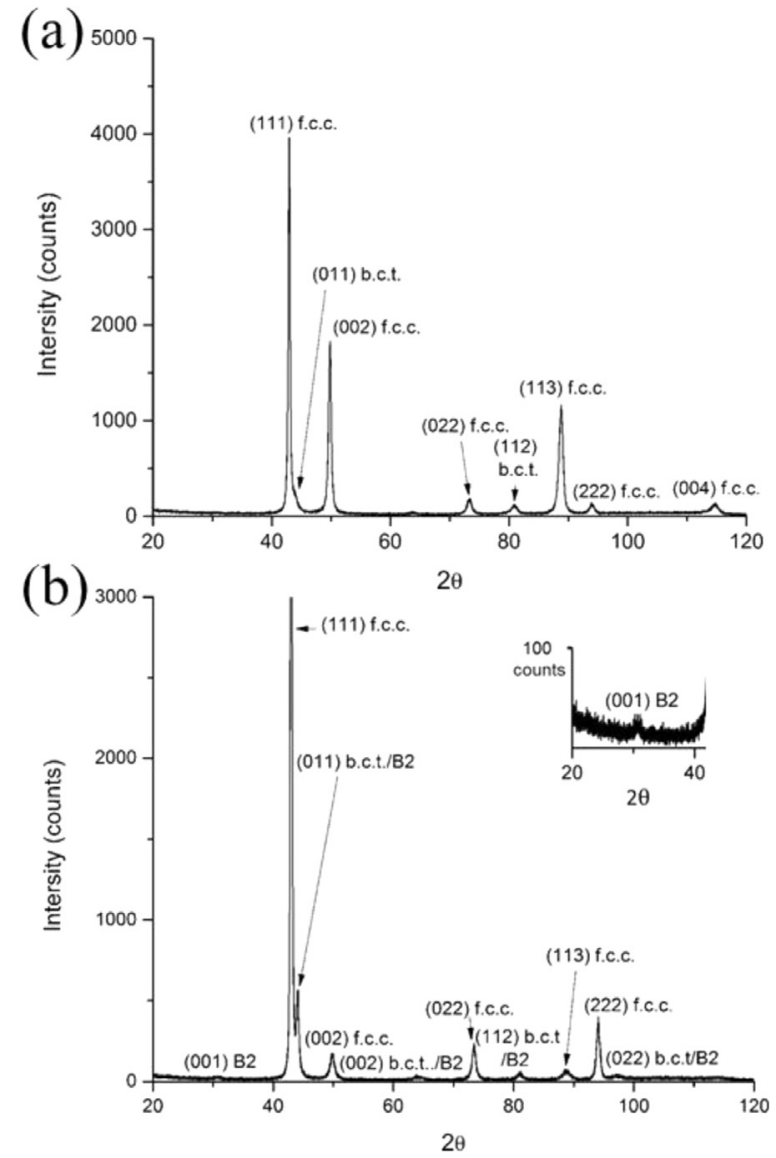

Fig. 3. XRD patterns for carbon-doped $\mathrm{Fe}_{36} \mathrm{Ni}_{18} \mathrm{Mn}_{33} \mathrm{Al}_{13}$ in (a) the as-cast state, and (b) $1 \mathrm{~h}$ annealed at $1000 \mathrm{~K}$ state. The inserted image in (b) shows the extra (001) peak of B2 phase in detail.

\section{Results}

Fig. 1 shows the microstructures of undoped and 1.26 at\% carbondoped $\mathrm{Fe}_{36} \mathrm{Ni}_{18} \mathrm{Mn}_{33} \mathrm{Al}_{13}$ alloys in both as-cast and annealed states: BSE images at high magnification for the annealed alloys are shown in Fig. 2. The as-cast undoped alloy exhibits a lamellar structure. The dark phase is B2 (ordered b.c.c.) and light phase is f.c.c in Fig. 1a based on previous studies [7]. The spacing between the B2 lamellae is $1.6 \mu \mathrm{m}$. The addition of carbon caused the lamellar structure to be replaced by a matrix containing a large irregular second phase, see Fig. 1b. The second phase particles consist of a net-like structure, as shown in Fig. 2b and d. After annealing at $1000 \mathrm{~K}$, needle-like precipitates were present in the f.c.c. matrix in both the undoped and carbon-doped $\mathrm{Fe}_{36} \mathrm{Ni}_{18} \mathrm{Mn}_{33} \mathrm{Al}_{13}$ alloys, see Fig. 1c-f. Table 1 summarizes the size distribution and the volume fraction of precipitates for both undoped and carbon-doped alloys annealed at $1 \mathrm{~h}$ and $72 \mathrm{~h}$. When the annealing time increased from $1 \mathrm{~h}$ to $72 \mathrm{~h}$, the average size of the precipitates increased from $139 \mathrm{~nm}$ to $409 \mathrm{~nm}$ for the undoped alloy, and from $149 \mathrm{~nm}$ to $495 \mathrm{~nm}$ for the carbon-doped alloy, respectively. Meanwhile, the growth of precipitate volume fraction shows the precipitation continued as the annealing proceeded in both undoped and carbondoped alloys. In addition, lamellar coarsening occurred as the annealing proceeded for the undoped alloys, i.e., the spacing between the B2 lamellae increased from $1.6 \mu \mathrm{m}$ in the as-cast state to $4.2 \mu \mathrm{m}$ in $72 \mathrm{~h}$ annealing state, as listed in Table 1.

$\mathrm{X}$-ray diffraction (XRD) patterns for the carbon-doped $\mathrm{Fe}_{36} \mathrm{Ni}_{18} \mathrm{Mn}_{33} \mathrm{Al}_{13}$ in the as-cast state and $1 \mathrm{~h}$ annealed state are presented in Fig. 3. The carbon-doped alloy contains both f.c.c. and b.c.t. (body-centered-tetragonal structure, further confirmed by TEM, see later) martensite phases in the as-cast state (Fig. 3a), while, as
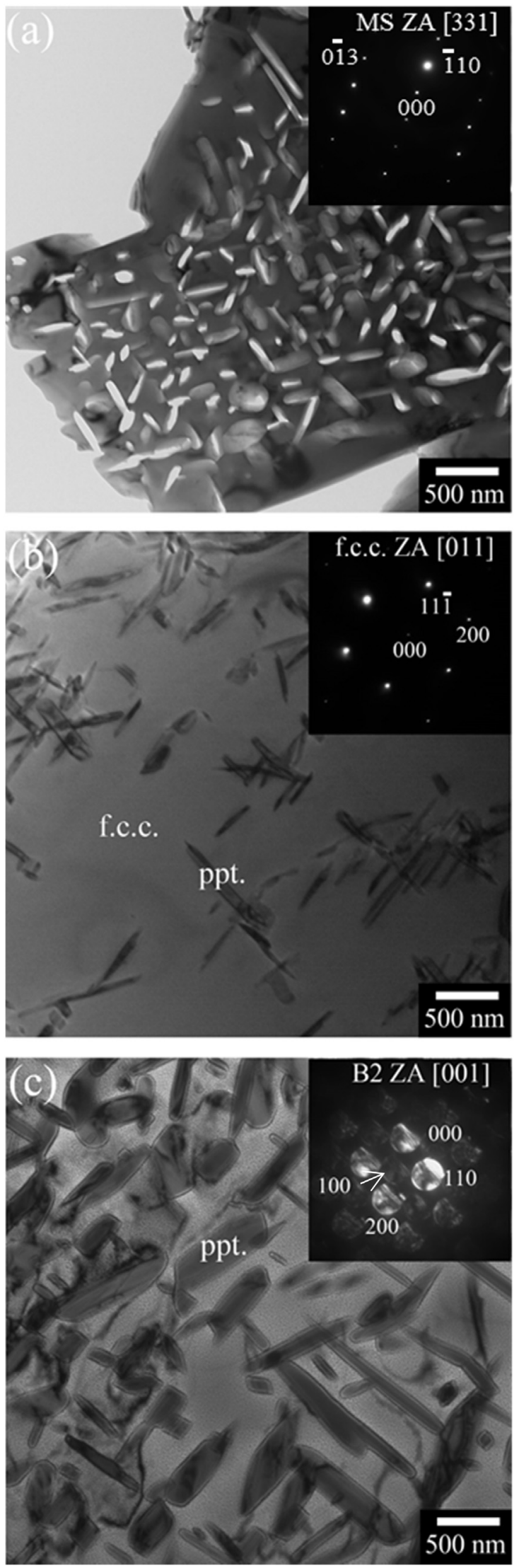

Fig. 4. $\mathrm{BF}$ TEM images of 1.26 at\% carbon-doped $\mathrm{Fe}_{36} \mathrm{Ni}_{18} \mathrm{Mn}_{33} \mathrm{Al}_{13}$ alloys annealed at $1000 \mathrm{~K}$ for (a) and (b) $1 \mathrm{~h}$, and (c) $72 \mathrm{~h}$. (a) shows the microstructure of the martensite phase and (b) shows precipitates (ppt.) in the f.c.c. matrix after $1 \mathrm{~h}$ annealing, and (c) shows the microstructure of the precipitates after $72 \mathrm{~h}$ annealing. The inserted SAD patterns confirm that the second phase is tetragonal martensite (MS), the matrix phase is f.c.c. structure, and the precipitates are $\mathrm{B} 2$ respectively. 
noted earlier, the undoped alloy consists of f.c.c. and B2 phases. The additional peaks appearing in the annealed carbon-doped alloy (Fig. 3b), indicate the precipitation is a B2 phase.

The bright field (BF) TEM images in Fig. 4 show the microstructures of the carbon-doped $\mathrm{Fe}_{36} \mathrm{Ni}_{18} \mathrm{Mn}_{33} \mathrm{Al}_{13}$ annealed at $1000 \mathrm{~K}$ for $1 \mathrm{~h}$ and $72 \mathrm{~h}$. Fig. $4 \mathrm{a}$ and b shows the microstructure of the irregular second phase and precipitates in $1 \mathrm{~h}$ annealed specimens. Selected area diffraction (SAD) patterns in Fig. $4 \mathrm{a}$ and $\mathrm{b}$ confirm that the irregular second phase is a tetragonal martensite and the matrix is f.c.c. structure. The converge beam electron diffraction (CBED) pattern in Fig. 4c from a precipitate after the $72 \mathrm{~h}$ anneal, after which the precipitates have grown significantly shows a B2 structure, which is
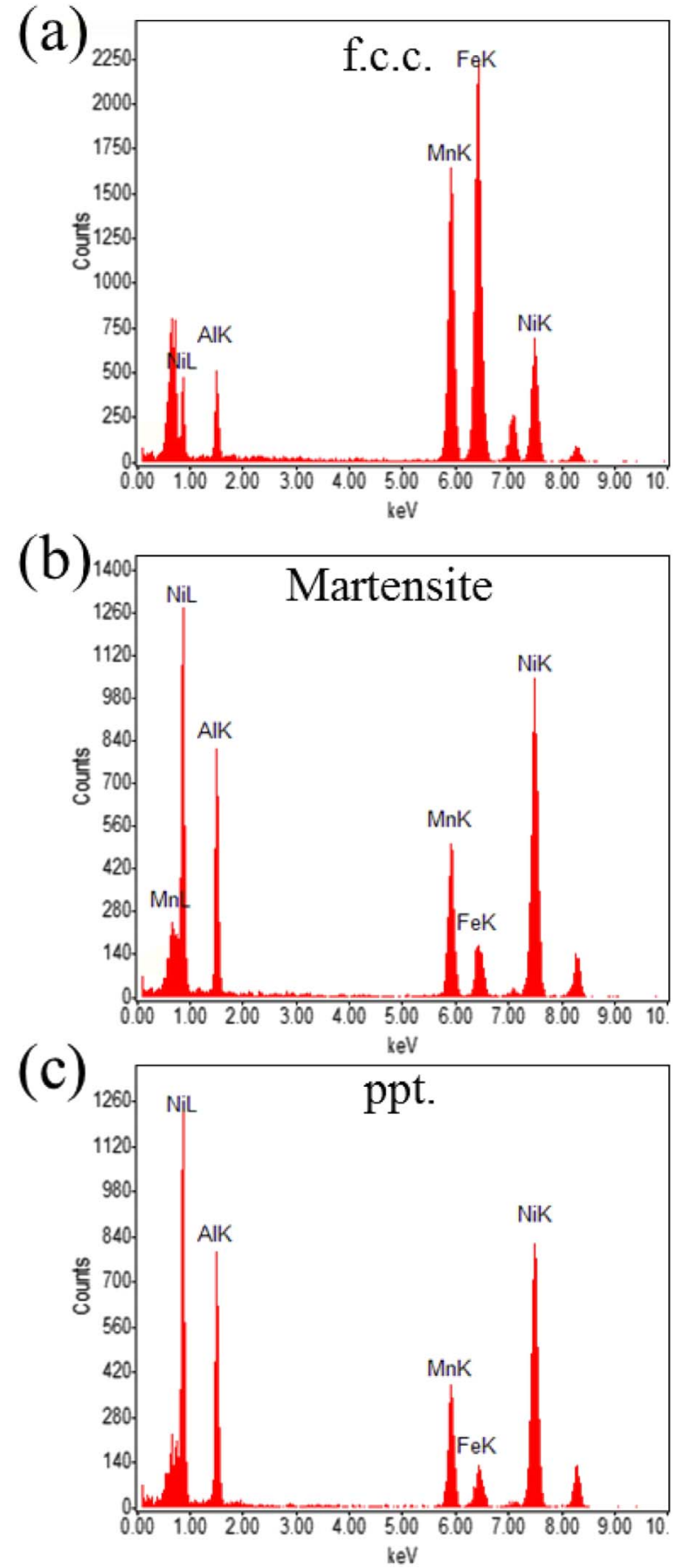

Fig. 5. X-ray spectra from the (a) f.c.c. matrix, (b) martensite and (c) B2 precipitates (ppt.) in the 1.26 at\% carbon-doped $\mathrm{Fe}_{36} \mathrm{Ni}_{18} \mathrm{Mn}_{33} \mathrm{Al}_{13}$ alloys annealed at $1000 \mathrm{~K}$ for $1 \mathrm{~h}$.
Table 2

Chemical compositions of phases determined by EDS (in at\%) from TEM specimens in undoped and carbon-doped $\mathrm{Fe}_{36} \mathrm{Ni}_{18} \mathrm{Mn}_{33} \mathrm{Al}_{13}$ alloys in as-cast, annealing and thermomechanical treated states. The chemical compositions of phases in undoped $\mathrm{Fe}_{36} \mathrm{Ni}_{18} \mathrm{Mn}_{33} \mathrm{Al}_{13}$ alloys are from [7]. Note that the carbon content is not listed due to the limited detection accuracy of EDS for light elements. MS and ppt. indicate the martensite and precipitate, respectively. The error bars indicate the standard deviation from five measurements.

\begin{tabular}{llllll}
\hline Alloy & Phase & $\mathbf{F e}$ & Ni & Mn & Al \\
\hline $\mathrm{Fe}_{36} \mathrm{Ni}_{18} \mathrm{Mn}_{33} \mathrm{Al}_{13}$ & f.c.c. & $39.6 \pm 0.5$ & $14.9 \pm 0.5$ & $30.9 \pm 0.8$ & $14.6 \pm 1.4$ \\
& B2 & $11.4 \pm 2.5$ & $38.0 \pm 3.1$ & $16.5 \pm 1.2$ & $34.1 \pm 2.6$ \\
$\mathrm{Fe}_{36} \mathrm{Ni}_{18} \mathrm{Mn}_{33} \mathrm{Al}_{13}$ & f.c.c. & $44.6 \pm 0.1$ & $11.5 \pm 0.2$ & $32.9 \pm 0.2$ & $11.0 \pm 0.5$ \\
$1000 \mathrm{~K}, 1 \mathrm{~h}$ & B2 & $7.6 \pm 0.8$ & $39.8 \pm 0.9$ & $15.5 \pm 0.5$ & $37.2 \pm 0.4$ \\
& ppt. & $6.8 \pm 0.5$ & $34.2 \pm 0.7$ & $14.0 \pm 0.7$ & $41.1 \pm 0.5$ \\
$\mathrm{Fe}_{36} \mathrm{Ni}_{18} \mathrm{Mn}_{33} \mathrm{Al}_{13} \mathrm{C}_{1.26}$ & f.c.c. & $43.3 \pm 1.5$ & $14.9 \pm 0.6$ & $30.2 \pm 0.6$ & $11.7 \pm 0.5$ \\
& MS & $10.7 \pm 2.2$ & $37.5 \pm 1.9$ & $22.9 \pm 1.6$ & $28.9 \pm 2.0$ \\
$\mathrm{Fe}_{36} \mathrm{Ni}_{18} \mathrm{Mn}_{33} \mathrm{Al}_{13} \mathrm{C}_{1.26}$ & f.c.c. & $43.3 \pm 1.0$ & $14.0 \pm 0.4$ & $30.9 \pm 1.2$ & $11.8 \pm 0.4$ \\
$1000 \mathrm{~K}, 1 \mathrm{~h}$ & MS & $5.3 \pm 0.9$ & $40.0 \pm 0.1$ & $15.3 \pm 0.5$ & $39.3 \pm 1.2$ \\
& ppt. & $4.1 \pm 0.2$ & $37.5 \pm 1.2$ & $13.0 \pm 1.2$ & $44.8 \pm 2.6$ \\
$\mathrm{Fe}_{36} \mathrm{Ni}_{18} \mathrm{Mn}_{33} \mathrm{Al}_{13} \mathrm{C}_{1.26}$ & f.c.c. & $43.1 \pm 1.0$ & $11.9 \pm 0.4$ & $34.7 \pm 1.0$ & $10.2 \pm 1.7$ \\
$\mathrm{~T}_{\mathrm{treatment}}$ & MS & $9.7 \pm 0.1$ & $34.9 \pm 0.1$ & $16.5 \pm 0.5$ & $38.9 \pm 0.5$ \\
& ppt. & $8.6 \pm 0.3$ & $34.7 \pm 0.6$ & $15.5 \pm 0.3$ & $41.1 \pm 0.8$ \\
\hline
\end{tabular}

consistent with our previous observation that B2-structured precipitates were formed in the undoped alloy during annealing [25]. Fig. 5 displays X-ray spectra from the f.c.c. matrix, the martensite phase and the $\mathrm{B} 2$ precipitates in the carbon-doped $\mathrm{Fe}_{36} \mathrm{Ni}_{18} \mathrm{Mn}_{33} \mathrm{Al}_{13}$ alloy annealed at $1000 \mathrm{~K}$ for $1 \mathrm{~h}$. The $\mathrm{Fe}$ and $\mathrm{Mn}$ are concentrated in the f.c.c. matrix, while the martensite phase was enriched in $\mathrm{Ni}$ and $\mathrm{Al}$. The composition of the $\mathrm{B} 2$ precipitates is close to that of the martensite, as illustrated in Fig. 5c. Table 2 summarizes the compositions for each phase in the undoped and carbon-doped $\mathrm{Fe}_{36} \mathrm{Ni}_{18} \mathrm{Mn}_{33} \mathrm{Al}_{13}$ alloys in both as-cast and annealed states. The EDS results show that the f.c.c. matrix, second phase (martensite phase), and precipitates have similar compositions in both the undoped and carbon-doped alloys.

The SE images in Fig. 6a and b show the microstructures of the recrystallized carbon-doped $\mathrm{Fe}_{36} \mathrm{Ni}_{18} \mathrm{Mn}_{33} \mathrm{Al}_{13}$ alloy after the $\mathrm{T} 1$ and T2 thermo-mechanical treatments (indicated as T1 and T2 alloy hereafter for simplicity), respectively. The grain size for the as-cast alloy was in the range of $100-300 \mu \mathrm{m}$ [7], while it decreased to $1.9 \mu \mathrm{m}$ in the T1 alloy and $4.5 \mu \mathrm{m}$ in the T2 alloy. The grain size of T2 alloy is larger than that of $\mathrm{T} 1$ alloy due to the longer annealing time. The martensite phase was dispersed during the cold-rolling and distributed among the grain boundaries of the f.c.c. phase. As shown in Fig. 6, precipitates were also formed inside the f.c.c. matrix after both $\mathrm{T} 1$ and T2 treatments. Fig. 7 presents BF TEM images for the recrystallized carbon-doped alloys after the $\mathrm{T} 1$ treatment. The SAD pattern in Fig. $7 \mathrm{~b}$ confirms that the precipitate inside the f.c.c. grain is a B2 structure. As shown in Table 2, the compositions for each phase in $\mathrm{T} 1$ alloy are similar to that in the annealed alloys.

Representative engineering stress-strain curves for the undoped and carbon-doped $\mathrm{Fe}_{36} \mathrm{Ni}_{18} \mathrm{Mn}_{33} \mathrm{Al}_{13}$ alloys in both as-cast and annealed states are shown in Fig. 8a. The corresponding variations of yield strength (Fig. 8b), ultimate tensile strength (UTS) (Fig. 8c), workhardening rate at $1 \%$ strain(Fig. $8 \mathrm{~d}$ ), and elongation to fracture (Fig. 8e) for alloys in the different conditions are also displayed. The yield strength, UTS, and work-hardening rate at $1 \%$ strain for both undoped and carbon-doped $\mathrm{Fe}_{36} \mathrm{Ni}_{18} \mathrm{Mn}_{33} \mathrm{Al}_{13}$ alloys increase significantly with increasing annealing time, i.e., the yield strength increased from $270 \mathrm{MPa}$ to $483 \mathrm{MPa}$ for the undoped alloy, and from $260 \mathrm{MPa}$ to $611 \mathrm{MPa}$ for the carbon-doped alloy, after annealing for $72 \mathrm{~h}$ at $1000 \mathrm{~K}$. Conversely, the elongation to fracture for both undoped and carbon-doped $\mathrm{Fe}_{36} \mathrm{Ni}_{18} \mathrm{Mn}_{33} \mathrm{Al}_{13}$ alloys decreases significantly as the annealing time increases, see Fig. 8e, but even the alloy with the lowest ductility shows $10 \%$ elongation.

Fig. 9a shows typical engineering stress-strain curves for carbondoped $\mathrm{Fe}_{36} \mathrm{Ni}_{18} \mathrm{Mn}_{33} \mathrm{Al}_{13}$ alloys after T1 and T2 thermo-mechanical 

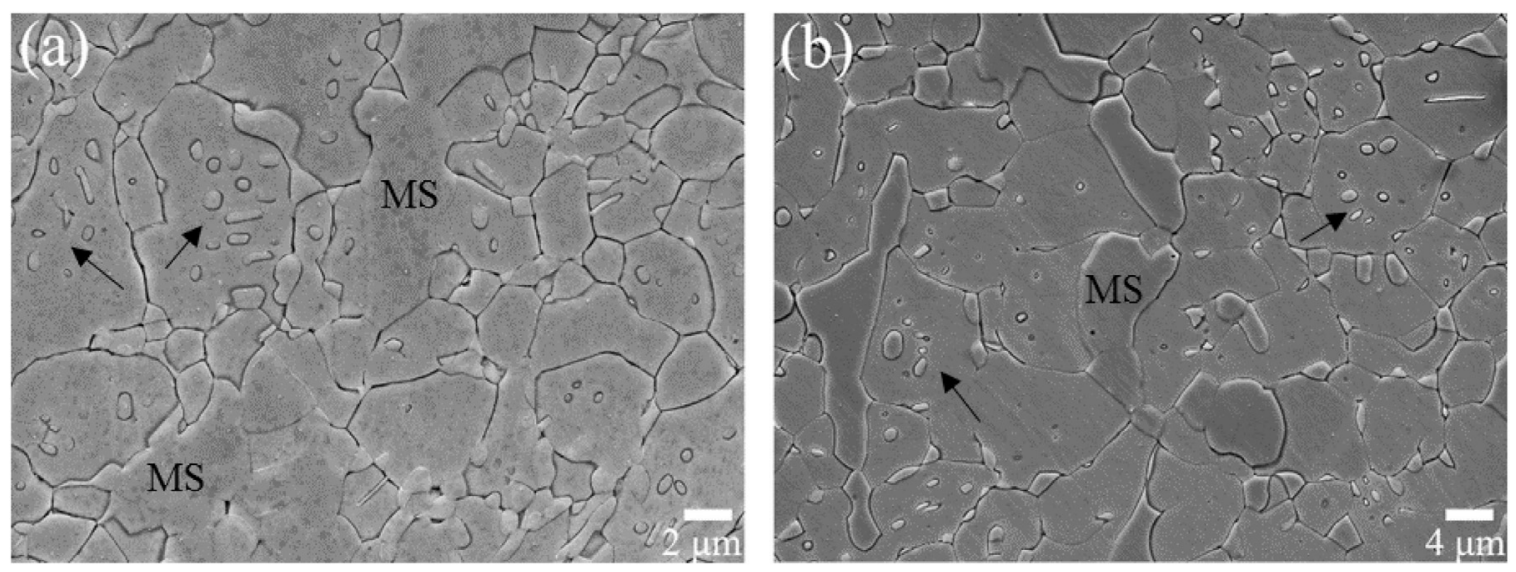

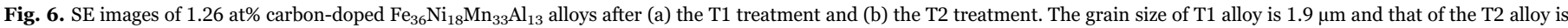
$4.5 \mu \mathrm{m}$. The martensite (MS) resides along the grain boundaries, while the B2 precipitates are inside the grains (see arrowed).

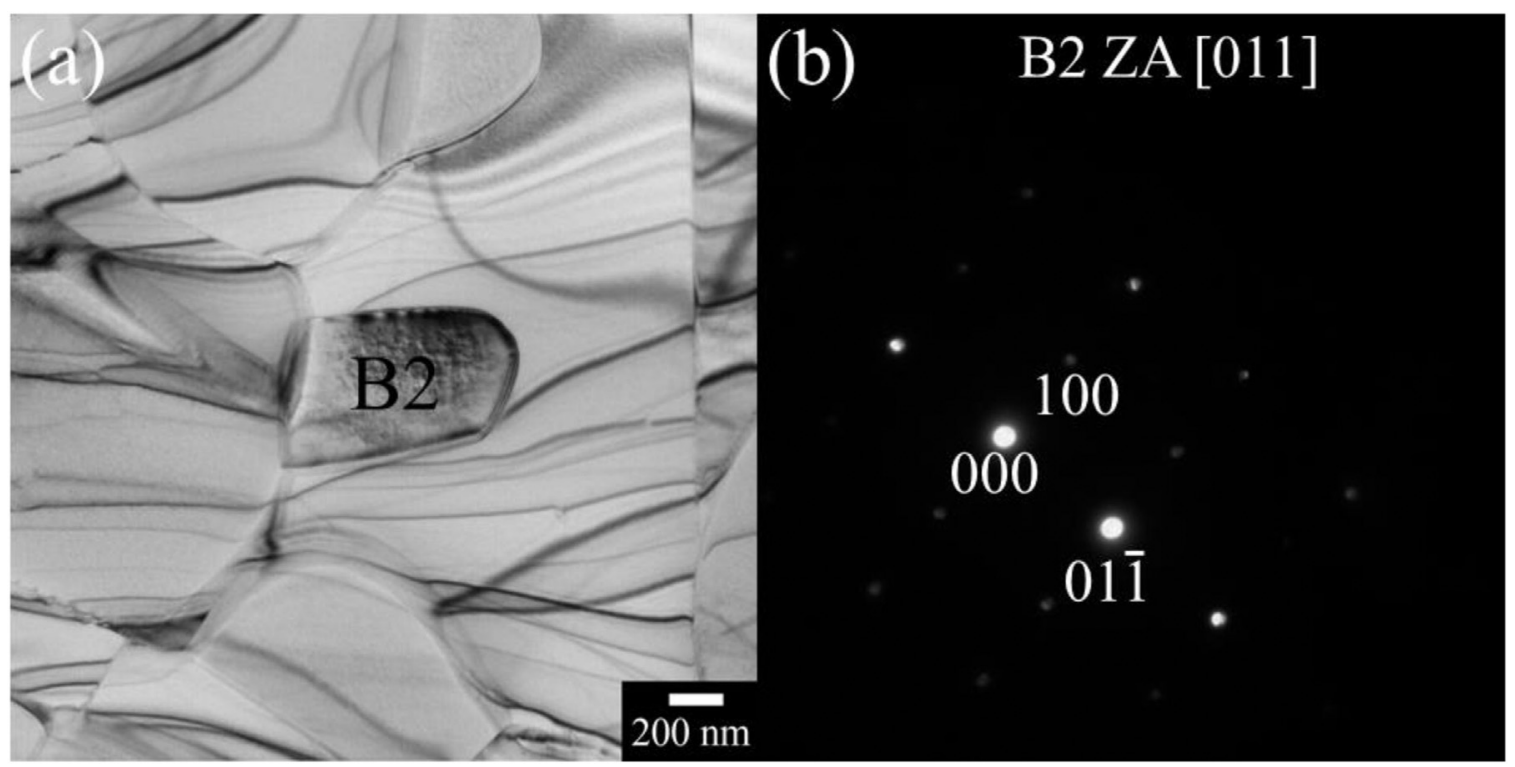

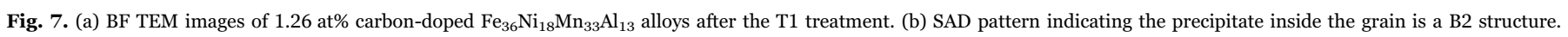

treatments, and Fig. 9b shows the variations of yield strength and elongation to fracture. The reduction of grain size to $1.9 \mu \mathrm{m}$ in the $\mathrm{T} 1$ alloy and $4.5 \mu \mathrm{m}$ in the $\mathrm{T} 2$ alloy produces an increase in strength but a decrease in ductility, i.e., the yield strength increased from $260 \mathrm{MPa}$ for the as-cast alloy to $532 \mathrm{MPa}$ for the T1 alloy and $426 \mathrm{MPa}$ for the T2 alloy, but the elongation decreased from $39.3 \%$ for as-cast alloy to 23 . $8 \%$ for the $\mathrm{T} 1$ alloy and $32.8 \%$ for the T2 alloy.

The dislocation substructures in the as-cast undoped alloy, as-cast carbon-doped alloy and $1 \mathrm{~h}$ annealed carbon-doped alloy strained to failure are shown in Fig. 10. For the undoped and annealed carbondoped alloys, a high density of randomly distributed dislocation were present in the f.c.c. phase. At these high levels of strain, microbands were also observed in the f.c.c. phase in the as-cast carbon-doped alloys, but not in the undoped alloy or the carbon-doped alloy containing precipitates. Slip trace analysis indicates that these microbands are oriented along $\{111\}$, which is consistent with our recent observations in a single-phase f.c.c. high entropy alloy [23].

The fracture surfaces for the carbon-doped $\mathrm{Fe}_{36} \mathrm{Ni}_{18} \mathrm{Mn}_{33} \mathrm{Al}_{13}$ alloy in the as-cast, $72 \mathrm{~h}$ annealed state and T2 thermo-mechanical treatment state are shown in Fig. 11. Dimples can be found in all three cases, of which the larger dimple size corresponds to higher elongations obtained in tensile test. Cleavage was also present along with the dimples in the alloy annealed for $72 \mathrm{~h}$, suggesting a mixture of ductile and brittle fracture mode.

\section{Discussion}

\subsection{Microstructures}

The lamellar structure of $\mathrm{Fe}_{36} \mathrm{Ni}_{18} \mathrm{Mn}_{33} \mathrm{Al}_{13}$ exhibits a strong dependence on chemical composition and processing conditions [15]. In the present study, when 1.26 at\% a carbon was added to $\mathrm{Fe}_{36} \mathrm{Ni}_{18} \mathrm{Mn}_{33} \mathrm{Al}_{13}$, the f.c.c./B2 lamellar was replaced by a f.c.c. matrix with a, b.c.t. martensite phase with an irregular shape. On one hand, the carbon dissolved in the f.c.c. phase, leading to the increase of lattice parameter from $3.6468 \AA$ in the undoped alloy [15] to the $3.6511 \AA$ in the carbon-doped alloy. On the other hand, the carbon addition caused the B2 (ordered b.c.c.) phase to change to clumps of b.c.t. martensite. The transformation from b.c.c. structure to b.c.t. structure is widely seen in the quenched Fe-C steels [26]. A similar phase transformation from $\mathrm{B} 2$ to $7 \mathrm{R}$ martensite has also been observed in undoped $\mathrm{Fe}_{36} \mathrm{Ni}_{18} \mathrm{Mn}_{33} \mathrm{Al}_{13}$, after cold-rolling and annealing [25]. The carbon atoms presumably occupy octahedral interstices, which produces lattice parameters of $\mathrm{a}=2.8802 \AA$ and $\mathrm{c}=2.9515 \AA$ i.e. a c/a ration of 1.03 .

In b.c.c. iron, carbon atoms sitting in octahedral sites on the unit cell edge lengthen the c-axis and dilate the a-axis and the c/a ration of the resulting martensite increases with increasing carbon [26]. The situation in B2 phases is somewhat different since the size of the edge 

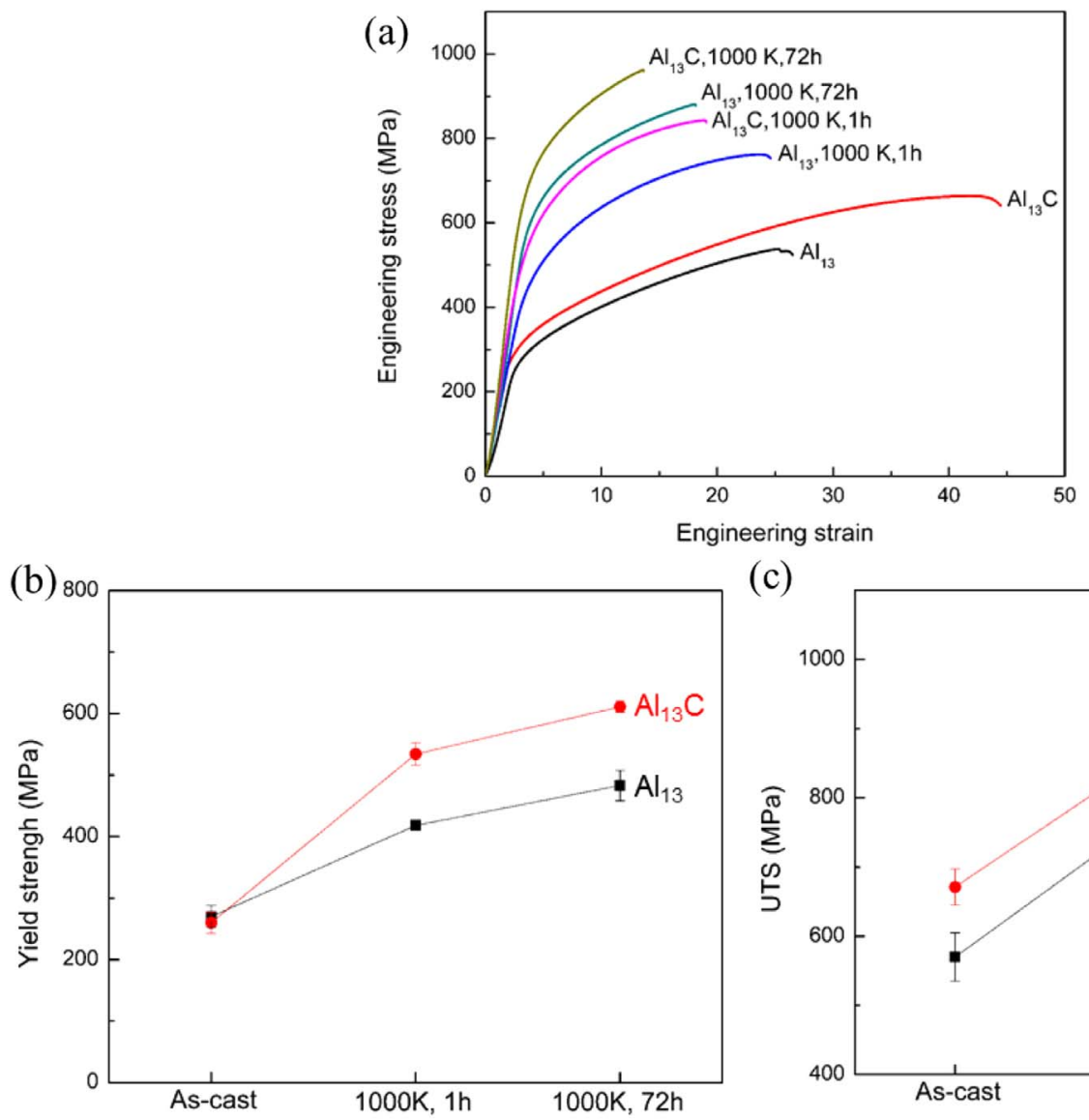

(c)
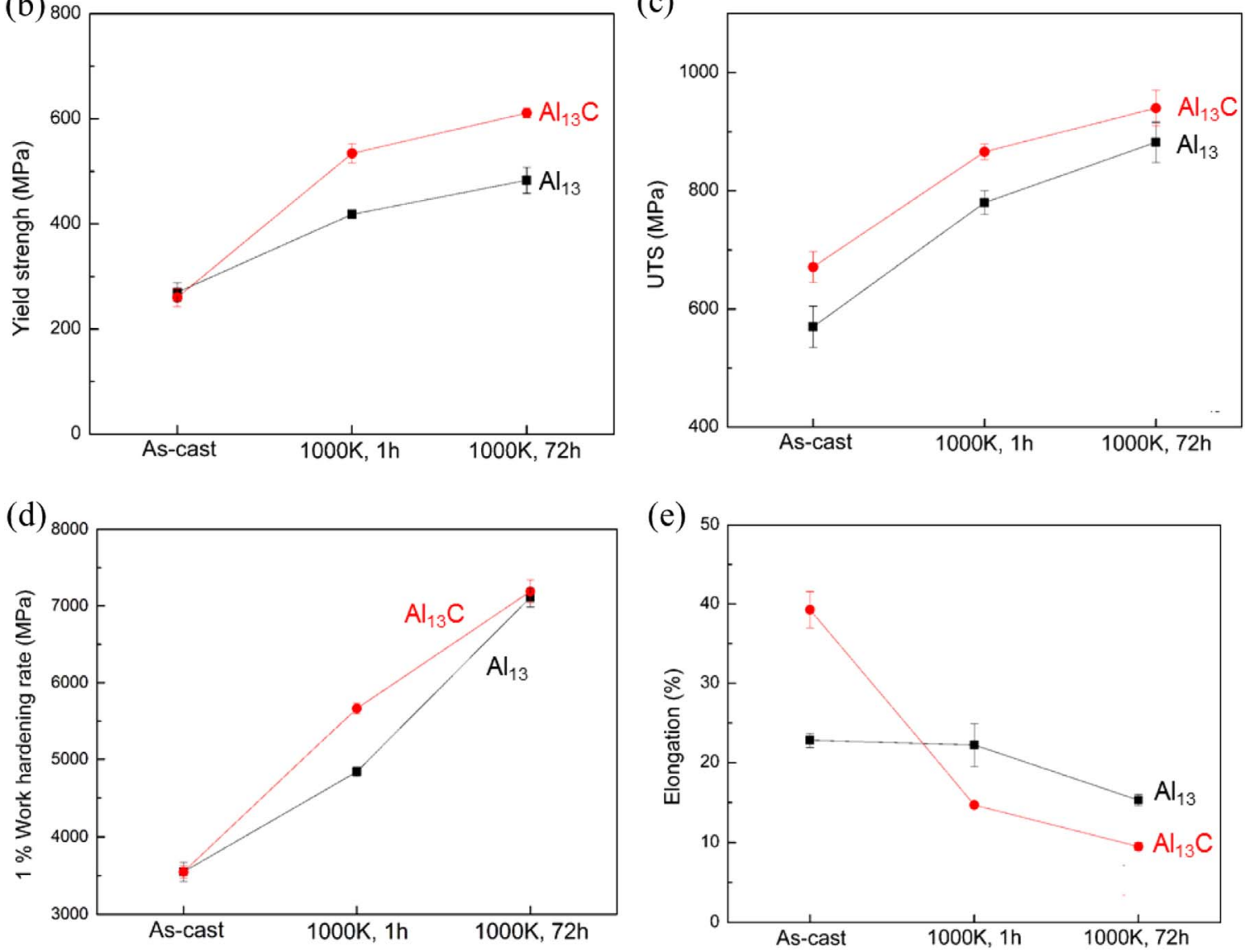

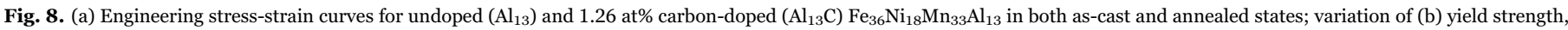

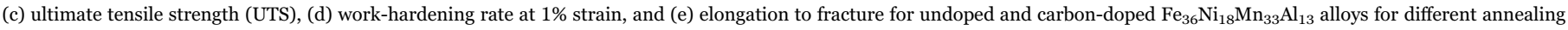
conditions.

octahedral site is different to the size of the octahedral in the center of the unit cell with their relative sizes depending on the ratio of the radii of the constituent atoms [27].

Needle-like B2-structured precipitates were found after annealing at $1000 \mathrm{~K}$ for both the undoped and carbon-doped $\mathrm{Fe}_{36} \mathrm{Ni}_{18} \mathrm{Mn}_{33} \mathrm{Al}_{13}$ alloys. Table 1 shows that the size and volume fraction of precipitates in undoped and doped are similar under the same annealing condition. Though the phase morphology in this as-cast carbon doped alloys has been completely changed, the compositions for each phase are very close, as seen in Table 2. Thus, it is not surprising to observe the similar precipitation kinetics in both undoped and carbon-doped $\mathrm{Fe}_{36} \mathrm{Ni}_{18} \mathrm{Mn}_{33} \mathrm{Al}_{13}$ alloys during annealing. Except for the precipitation, the lamellar coarsening occurred for the undoped alloys upon annealing at $1000 \mathrm{~K}$, of which the lamellar spacing increased from the 2.3-
$4.2 \mu \mathrm{m}$ with an increase in annealing time from $1 \mathrm{~h}$ to $72 \mathrm{~h}$. This is consistent with observations for $\mathrm{Fe}_{36} \mathrm{Ni}_{18} \mathrm{Mn}_{33} \mathrm{Al}_{13} \mathrm{Ti}_{\mathrm{x}}$ alloys, where significant coarsening of the lamellae was found upon annealing at $1173 \mathrm{~K}$ [15].

The recrystallized carbon-doped $\mathrm{Fe}_{36} \mathrm{Ni}_{18} \mathrm{Mn}_{33} \mathrm{Al}_{13}$ alloys show a very fine microstructure with grain sizes of $1.9 \mu \mathrm{m}$ for the T1 alloy and $4.5 \mu \mathrm{m}$ for the T2 alloy, see Fig. 6, The fine-grained structure after recrystallization can be ascribed to the pinning effect on grain boundaries from the martensite during recrystallization. The dispersed martensite particles are capable of exerting a drag force on migrating grain boundaries, and thus, impede the grain growth during the recrystallization process [28]. Baker et al. [19] showed that a very fine grain size of $0.5 \mu \mathrm{m}$ can be achieved in a f.c.c./B2 $\mathrm{Fe}_{28.2} \mathrm{Ni}_{18.8} \mathrm{Mn}_{32.9} \mathrm{Al}_{14.1} \mathrm{Cr}_{6}$ alloy after recrystallization owing to the drag effect of the $\mathrm{B} 2$ phase. 


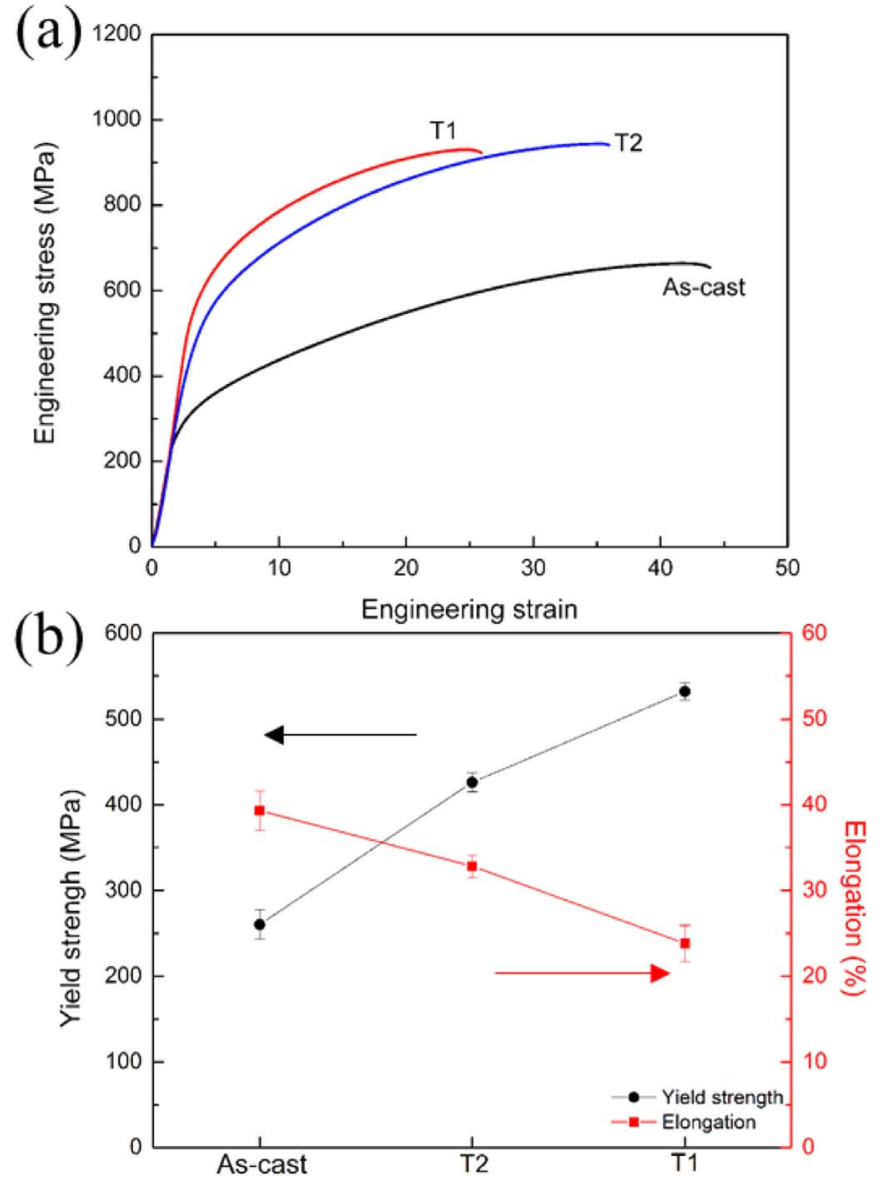

Fig. 9. (a) Engineering stress-strain curves and (b) yield strength and elongation for ascast and recrystallized 1.26 at\% carbon-doped $\mathrm{Fe}_{36} \mathrm{Ni}_{18} \mathrm{Mn}_{33} \mathrm{Al}_{13}$ alloys after $\mathrm{T} 1$ and $\mathrm{T} 2$ treatment.

\subsection{Yield strength and work-hardening rate}

The yield strength $\left(\sigma_{\mathrm{y}}\right)$ of the $\mathrm{Fe}_{36} \mathrm{Ni}_{18} \mathrm{Mn}_{33} \mathrm{Al}_{13}$ alloys can be described by the following expression:

$\sigma_{\mathrm{y}}=\sigma_{\mathrm{fr}}+\sigma_{\mathrm{b}}+\sigma_{\mathrm{ppt}}$

where $\sigma_{\mathrm{fr}}$ is the lattice friction stress, $\sigma_{\mathrm{b}}$ is the strength increase associated with the phase boundaries and grain boundaries, and $\sigma_{\mathrm{ppt}}$ is stress from the precipitate strengthening. In $\mathrm{Fe}_{36} \mathrm{Ni}_{18} \mathrm{Mn}_{33} \mathrm{Al}_{13}$ multicomponent alloys, we can not define the solute and solvent atoms since the constituents are distributed randomly in the lattice. Hence, the solid solution strengthening $\left(\sigma_{\mathrm{ss}}\right)$ is commonly embedded in the lattice friction stress in multicomponent alloys, as seen in $\mathrm{Fe}_{28.2} \mathrm{Ni}_{18.8} \mathrm{Mn}_{32.9} \mathrm{Al}_{14.1} \mathrm{Cr}_{6}$ alloy [29] and $\mathrm{FeNiCoCr}$ alloy [30]. Both the grain boundaries and the martensite phase are impediments to dislocation movement, which produces a boundary strengthening effect. The grain boundary strengthening follows a Hall-Petch relationship $[31,32] \sigma_{\mathrm{gb}} \sim \lambda^{-0.5}$, while the phase boundary strengthening is described by a modified Hall-Petch type relationship in FeNiMnAl alloy system $[7,15] \sigma_{\mathrm{pb}} \sim \lambda^{-1}$; where $\lambda$ is the grain size or phase spacing. The precipitate strengthening effect results from dislocations bowing around the precipitates, which for large precipitates can be expressed by [33]:

$\sigma_{\mathrm{ppt}}=\frac{\mathrm{Gb}}{\mathrm{L}}$

where $\mathrm{G}$ is the shear modulus, $\mathrm{b}$ is the Burgers' vector, and $\mathrm{L}$ is the precipitate spacing. In the following, the variation of yield strength for undoped and 1.26 at\% carbon-doped alloys in different conditions are discussed based on the strengthening mechanisms noted above.
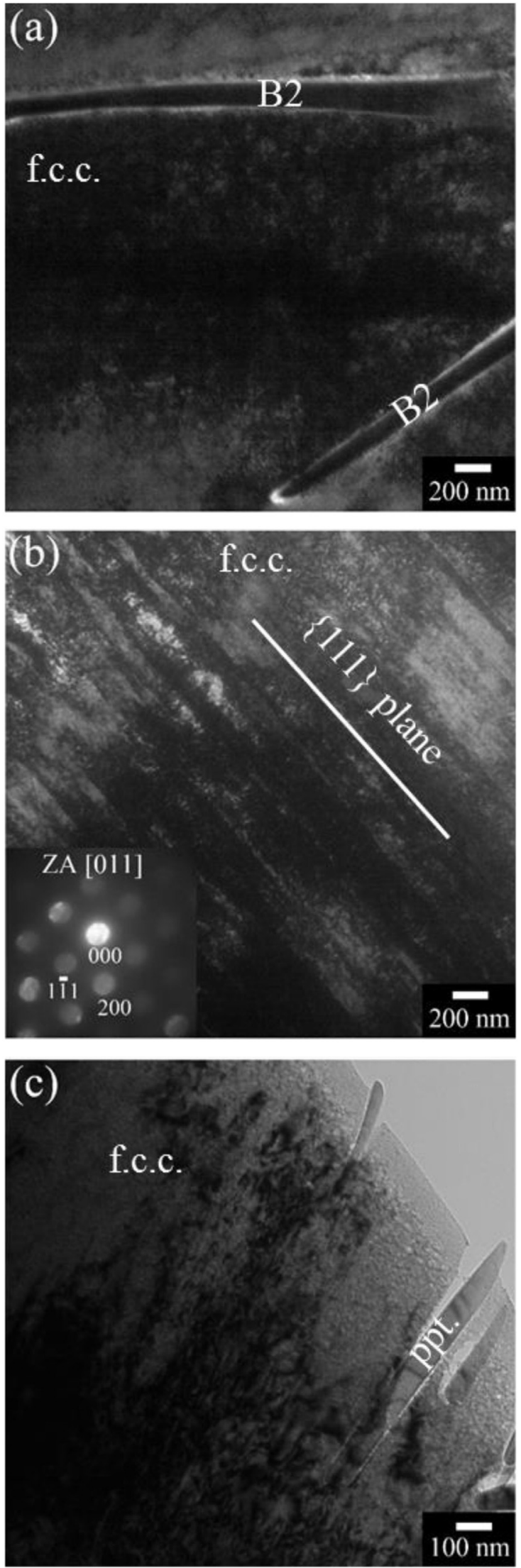

Fig. 10. Dislocation substructures in the (a) undoped $\mathrm{Fe}_{36} \mathrm{Ni}_{18} \mathrm{Mn}_{33} \mathrm{Al}_{13}$ alloy, and in the 1.26 at\% carbon-doped $\mathrm{Fe}_{36} \mathrm{Ni}_{18} \mathrm{Mn}_{33} \mathrm{Al}_{13}$ alloys in (b) the as-cast state and (c) after annealing at $1000 \mathrm{~K}$ for $1 \mathrm{~h}$ strained to failure. The slip trace shows that the microbands are oriented along $\{111\}$. 

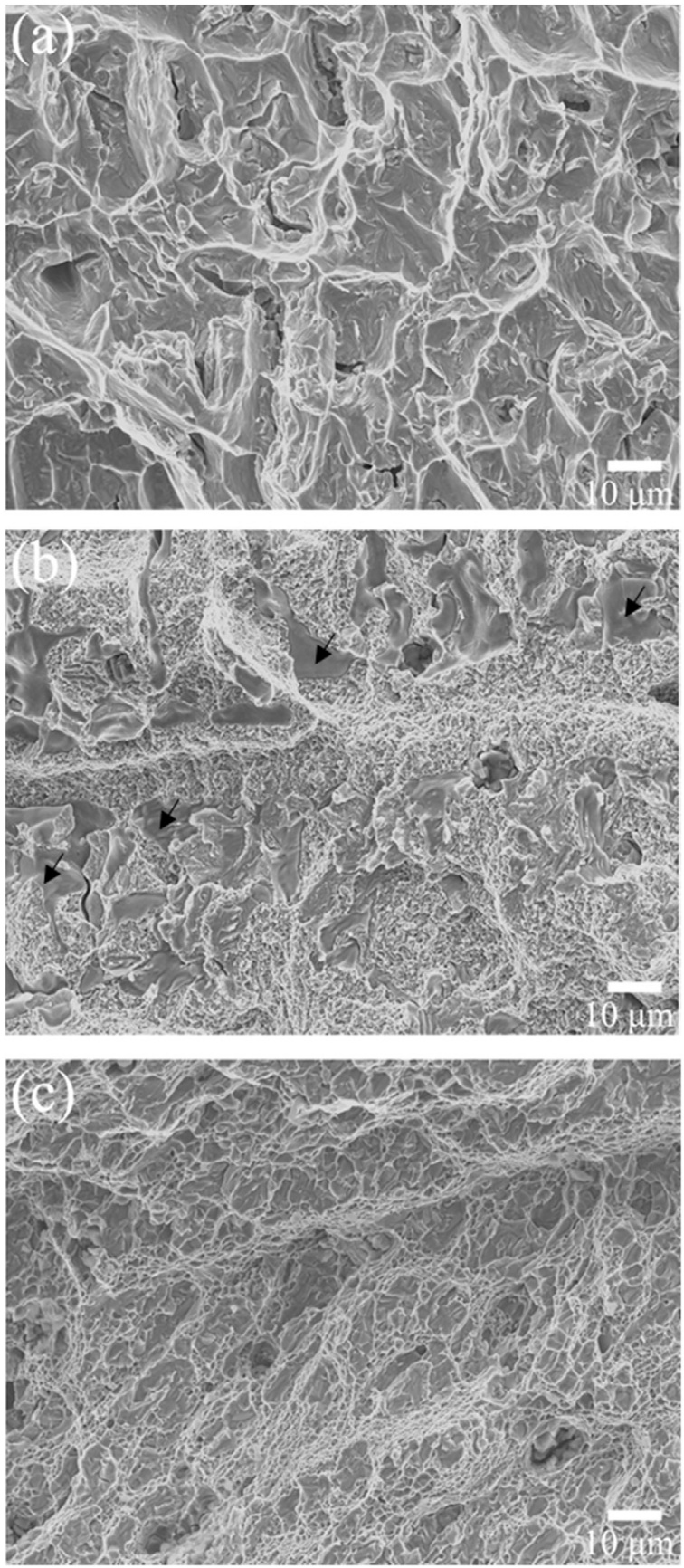

Fig. 11. Fracture surfaces of 1.26 at\% carbon-doped $\mathrm{Fe}_{36} \mathrm{Ni}_{18} \mathrm{Mn}_{33} \mathrm{Al}_{13}$ alloys in (a) ascast state, (b) annealed at $1000 \mathrm{~K}$ for $72 \mathrm{~h}$, and (c) recrystallized state after $\mathrm{T} 1$ treatment. Some cleavage steps are arrowed in (b).

The yield strength of carbon-doped $\mathrm{Fe}_{36} \mathrm{Ni}_{18} \mathrm{Mn}_{33} \mathrm{Al}_{13}$ alloy ( 26 $\mathrm{MPa})$ is close to that of the undoped $\mathrm{Fe}_{36} \mathrm{Ni}_{18} \mathrm{Mn}_{33} \mathrm{Al}_{13}$ alloy $(\sim 27$ $\mathrm{MPa}$ ) in as-cast state, as shown in Fig. 8. For the as-cast and annealed alloys, the contribution from grain boundary strengthening is likely to be very small due to the large grain size in the range of $100-300 \mu \mathrm{m}$. Therefore, the dominant contributions to the yield strength for both the undoped and carbon-doped alloys results from the lattice friction and phase boundary strengthening. For the carbon-doped alloys, the carbon atoms are dissolved in the lattice, improving the lattice friction stress via the interstitial strengthening. The transformation of phase morphology from lamellar-structured to particle-structured, however, reduced the effectiveness of phase boundary strengthening. The decrease in phase boundary strengthening counteracted the increase in lattice friction stress. As a result, the yield strength is close for undoped and carbon-doped $\mathrm{Fe}_{36} \mathrm{Ni}_{18} \mathrm{Mn}_{33} \mathrm{Al}_{13}$ alloys in as-cast state.

The yield strength increases significantly with increasing annealing times for both undoped and doped $\mathrm{Fe}_{36} \mathrm{Ni}_{18} \mathrm{Mn}_{33} \mathrm{Al}_{13}$ alloys because of the $\mathrm{B} 2$ precipitation. As listed in Table 1, a growing number of precipitates are formed after longer annealing time, causing the enhancement of precipitate strengthening effects in alloys. But for undoped $\mathrm{Fe}_{36} \mathrm{Ni}_{18} \mathrm{Mn}_{33} \mathrm{Al}_{13}$ alloys, the lamellar spacing increases as annealing proceeds (see Table 1), which reduces the phase boundary strengthening. As a consequence, the increase in yield strength after annealing in the carbon-doped alloys is higher than that of the undoped alloy, i.e., the improvement of yield strength after $1 \mathrm{~h}$ annealing is $274 \mathrm{MPa}$ for the doped alloy and $148 \mathrm{MPa}$ for the undoped alloy, respectively, even though the size and volume fraction of the precipitate are similar in both alloys.

The yield strengths of the T1 and T2 alloy is much higher than that of the as-cast carbon-doped alloy (see Fig. 9b), since the grain boundary strengthening is significant for recrystallized T1 and T2 alloys. For the T1 and T2 alloy, both second phase and precipitate strengthening occur; however, the grain size of the T1 alloy $(1.9 \mu \mathrm{m})$ is smaller than that of the T2 alloy $(4.5 \mu \mathrm{m})$, which produces a stronger grain boundary strengthening in the T1 alloy. Thus, the yield strength of the T1 alloy is higher than that of the T2 alloy, as shown in Fig. 9b.

The work-hardening rate at $1 \%$ strain for both undoped and Cdoped alloys increases with increasing of annealing time (see Fig. 8d), showing the same trend as the yield strength. The work-hardening rate for both alloys increased up to $\sim 700 \mathrm{MPa}$ after $72 \mathrm{~h}$ annealing at $1000 \mathrm{~K}$, which exhibited a similar value to $\mathrm{Fe}_{28} \mathrm{Ni}_{18} \mathrm{Mn}_{33} \mathrm{Al}_{21}$ alloys after a long annealing (100-250 h) at $1173 \mathrm{~K}$ [34]. More precipitates form as the annealing time increases, which exerts a stronger retard to dislocation motions during deformation and thus, leads to the higher work-hardening.

\subsection{Ductility}

Generally, the ductility of both undoped and doped $\mathrm{Fe}_{36} \mathrm{Ni}_{18} \mathrm{Mn}_{33} \mathrm{Al}_{13}$ alloys decreases as the strength increases, which is a typical behavior for most metallic materials [35]. It is worth noting that, although the yield strength is similar for the doped and undoped $\mathrm{Fe}_{36} \mathrm{Ni}_{18} \mathrm{Mn}_{33} \mathrm{Al}_{13}$ alloy in the as-cast state, the ductility of the carbon-doped alloy is far better than that of the undoped $\mathrm{Fe}_{36} \mathrm{Ni}_{18} \mathrm{Mn}_{33} \mathrm{Al}_{13}$ alloy, i.e., an elongation of $39.3 \%$ for the carbon-doped alloy versus $22.8 \%$ for the undoped $\mathrm{Fe}_{36} \mathrm{Ni}_{18} \mathrm{Mn}_{33} \mathrm{Al}_{13}$ alloy. As shown in Fig. 10b, microbands were formed in the f.c.c. matrix of the carbon-doped alloys at a high strain. Previous studies indicated that the formation of microbands allows relaxation of the local strain and provides extra accommodation of plasticity, which leads to an increase of ductility [23]. Thus, microband formation may account for the remarkable increase of ductility in the carbon-doped alloy, as also seen in austenite high Mn steels $[36,37]$ and a f.c.c. high entropy alloy $[23,38]$. The occurrence of microband is related to the increase of lattice friction stress due to the addition of carbon solutes [23]. Microbands were observed in the carbondoped alloy (Fig. 10b) but not the undoped alloy (Fig. 10a). However, for the carbon-doped alloy annealed at $1000 \mathrm{~K}$ for $1 \mathrm{~h}$, microbands are no longer seen and a random distribution of dislocation is found in f.c.c. phase, see Fig. 10c. The formation of microbands relies on the subdivision of grains during deformation [23]. In the annealed carbon-doped alloy precipitates distributed inside the f.c.c. phase hinders the grain subdivision as the strain is increased and, thus, impedes the formation of microbands. A similar phenomenon was observed in a thermo-mechanically processed 1.1 at\% carbon-doped HEA with a very fine distribution of grain boundaries and carbides [38]. Correspondingly, the annealed carbon-doped alloy exhibits much lower ductility than the as-cast alloy, i.e., the elongation reduced sharply from $39.3 \%$ in the as-cast state to $14.7 \%$ in the $1 \mathrm{~h}$ annealed state. 


\section{Conclusions}

The effects of carbon and thermo-mechanical treatment on the microstructure and room temperature mechanical properties of lamellar-structured B2/f.c.c. $\mathrm{Fe}_{36} \mathrm{Ni}_{18} \mathrm{Mn}_{33} \mathrm{Al}_{13}$ were studied and the following observed:

1. The addition of carbon altered the microstructure from a lamellar structure to randomly-distributed, coarse two-phase structure, and further induced a transformation from a B2 (ordered b.c.c.) phase to the b.c.t. martensite phase due to the occupation of octahedral interstices by carbon atoms.

2. B2-structure needles precipitate in both undoped and carbon-doped $\mathrm{Fe}_{36} \mathrm{Ni}_{18} \mathrm{Mn}_{33} \mathrm{Al}_{13}$ alloys upon annealing, leading to a sharp increase in strength but a decrease in ductility. With increasing annealing time, the precipitation continues and the coarsening for individual precipitate occurs in both alloys.

3. Thermo-mechanical treatments of the carbon-doped alloy reduced the as-cast grain size from 100 to $300 \mu \mathrm{m}$ to $1.9-4.5 \mu \mathrm{m}$ depending on the processing, resulting in a significant improvement in strength via grain boundary strengthening.

4. The carbon solute increases the lattice friction stress of f.c.c. phase in as-cast carbon-doped $\mathrm{Fe}_{36} \mathrm{Ni}_{18} \mathrm{Mn}_{33} \mathrm{Al}_{13}$ and thus, leads to the formation of microbands during deformation, which further results in a remarkable increase in the ductility of the alloy.

\section{Acknowledgements}

This research was supported at Dartmouth College by the US Department of Energy (DOE), Office of Basic Energy Sciences Grant DE-FG02-07ER46392. The views and conclusions contained herein are those of the authors and should not be interpreted as necessarily representing official policies, either expressed or implied of the DOE or the U.S. Government. We would like to thank Dr. Shuang Gao in The Graduate School at Shenzhen, Tsinghua University for helping with indexing diffraction patterns.

\section{References}

[1] Y. Liao, I. Baker, Evolution of the microstructure and mechanical properties of eutectic $\mathrm{Fe}_{30} \mathrm{Ni}_{20} \mathrm{Mn}_{35} \mathrm{Al}_{15}$, J. Mater. Sci. 46 (2011) 2009-. http://dx.doi.org/ 10.1007/s10853-010-5197-6.

[2] Y. Liao, I. Baker, On the room-temperature deformation mechanisms of lamellarstructured $\mathrm{Fe}_{30} \mathrm{Ni}_{20} \mathrm{Mn}_{35} \mathrm{Al}_{15}$, Mater. Sci. Eng. A 528 (2011) 3998-. http:// dx.doi.org/10.1016/j.msea.2011.01.089.

[3] Y. Liao, I. Baker, Microstructure and room-temperature mechanical properties of $\mathrm{Fe}_{30} \mathrm{Ni}_{20} \mathrm{Mn}_{35} \mathrm{Al}_{15}$, Mater. Charact. 59 (2008) 1546-. http://dx.doi.org/10.1016/ j.matchar.2008.01.017.

[4] Y. Liao, F. Meng, I. Baker, Environmental embrittlement of two-phase $\mathrm{Fe}_{30} \mathrm{Ni}_{20} \mathrm{Mn}_{35} \mathrm{Al}_{15}$, Intermetallics 19 (2011) 1533-. http://dx.doi.org/10.1016/ j.intermet.2011.05.023.

[5] F. Meng, J. Qiu, I. Baker, The effects of chromium on the microstructure and tensile behavior of $\mathrm{Fe}_{30} \mathrm{Ni}_{20} \mathrm{Mn}_{35} \mathrm{Al}_{15}$, Mater. Sci. Eng. A 586 (2013) 45-. http:// dx.doi.org/10.1016/j.msea.2013.08.005.

[6] F. Meng, I. Baker, P.R. Munroe, The effects of environment on the dry sliding wear of eutectic $\mathrm{Fe}_{30} \mathrm{Ni}_{20} \mathrm{Mn}_{35} \mathrm{Al}_{15}$, J. Mater. Sci. 47 (2012) 4827-. http://dx.doi.org/ 10.1007/s10853-012-6341-2.

[7] F. Meng, J. Qiu, I. Baker, Effect of Al content on the microstructure and mechanical behavior of two-phase FeNiMnAl alloys, J. Mater. Sci. 49 (2014) 1973-. http:// dx.doi.org/10.1007/s10853-013-7884-6.

[8] K. Maruyama, N. Yamada, H. Sato, Effects of lamellar spacing on mechanical properties of fully lamellar Ti-39.4 mol\%Al alloy, Mater. Sci. Eng. A 319-321 (2001) 360-. http://dx.doi.org/10.1016/S0921-5093(01)00926-1.

[9] Y. Umakoshi, T. Nakano, T. Yamane, The effect of orientation and lamellar structure on the plastic behavior of TiAl crystals, Mater. Sci. Eng. A 152 (1992) 81-. http://dx.doi.org/10.1016/0921-5093(92)90050-B.

[10] A. Misra, R. Gibala, Room-temperature deformation behavior of directionally solidified multiphase Ni-Fe-Al alloys, Metall. Mater. Trans. A 28 (1997) 795-. http://dx.doi.org/10.1007/s11661-997-0066-x.
[11] G. Sauthoff, Multiphase intermetallic alloys for structural applications, Intermetallics 8 (2000) 1101-. http://dx.doi.org/10.1016/S0966-9795(00)00045 5.

[12] S. Guha, P.R. Munroe, I. Baker, Room temperature deformation behavior of multiphase Ni-20 at\%Al-30 at\%Fe and its constituent phases, Mater. Sci. Eng. A 131 (1991) 27-. http://dx.doi.org/10.1016/0921-5093(91)90341-J.

[13] J.M. Hyzak, I.M. Bernstein, The role of microstructure on the strength and toughness of fully pearlitic steels, Metall. Trans. A 7 (1976) 1217-. http:// dx.doi.org/10.1007/BF02656606.

[14] M. Dollar, I.M. Bernstein, A.W. Thompson, Influence of deformation substructure on flow and fracture of fully pearlitic steel, Acta Metall. 36 (1988) 311-. http:/ dx.doi.org/10.1016/0001-6160(88)90008-9.

[15] Z. Wang, M. Wu, Z. Cai, S. Chen, I. Baker, Effect of Ti content on the microstructure and mechanical behavior of $\left(\mathrm{Fe}_{36} \mathrm{Ni}_{18} \mathrm{Mn}_{33} \mathrm{Al}_{13}\right)_{100-\mathrm{x}} \mathrm{Ti}_{\mathrm{x}}$ high entropy alloys, Intermetallics 75 (2016) 79-. http://dx.doi.org/10.1016/j.intermet.2016.06.001.

[16] A.J. Ardell, Precipitation hardening, Metall. Trans. A 16 (1985) 2131-. http:// dx.doi.org/10.1007/BF02670416.

[17] J.A. Hanna, I. Baker, M.W. Wittmann, P.R. Munroe, A new high-strength spinoda alloy, J. Mater. Res. 20 (2005) 791-. http://dx.doi.org/10.1557/JMR.2005.0136.

[18] J.Y. He, H. Wang, H.L. Huang, X.D. Xu, M.W. Chen, Y. Wu, et al., A precipitationhardened high-entropy alloy with outstanding tensile properties, Acta Mater. 102 (2016) 187-. http://dx.doi.org/10.1016/j.actamat.2015.08.076.

[19] I. Baker, F. Meng, M. Wu, A. Brandenberg, Recrystallization of a novel two-phase FeNiMnAlCr high entropy alloy, J. Alloy. Compd. 656 (2016) 458-. http:// dx.doi.org/10.1016/j.jallcom.2015.09.264.

[20] I.S. Wani, T. Bhattacharjee, S. Sheikh, Y.P. Lu, S. Chatterjee, P.P. Bhattacharjee, et al., Ultrafine-grained $\mathrm{AlCoCrFeNi}_{2.1}$ eutectic high-entropy alloy, Mater. Res. Lett., 0(n.d.), 1-6. http://dx.doi.org/10.1080/21663831.2016.1160451.

[21] Z. Wu, C.M. Parish, H. Bei, Nano-twin mediated plasticity in carbon-containing FeNiCoCrMn high entropy alloys, J. Alloy. Compd. 647 (2015) 815-. http:// dx.doi.org/10.1016/j.jallcom.2015.05.224.

[22] N.D. Stepanov, N.Y. Yurchenko, M.A. Tikhonovsky, G.A. Salishchev, Effect of carbon content and annealing on structure and hardness of the CoCrFeNiMn-based high entropy alloys, J. Alloy. Compd. 687 (2016) 59-. http://dx.doi.org/10.1016/ j.jallcom.2016.06.103.

[23] Z. Wang, I. Baker, Z. Cai, S. Chen, J.D. Poplawsky, W. Guo, The effect of interstitial carbon on the mechanical properties and dislocation substructure evolution in $\mathrm{Fe}_{40.4} \mathrm{Ni}_{11.3} \mathrm{Mn}_{34.8} \mathrm{Al}_{7.5} \mathrm{Cr}_{6}$ high entropy alloys, Acta Mater. 120 (2016) 228-. http://dx.doi.org/10.1016/j.actamat.2016.08.072.

[24] Z. Wang, I. Baker, Interstitial strengthening of a f.c.c. FeNiMnAlCr high entropy alloy, Mater. Lett. 180 (2016) 153-. http://dx.doi.org/10.1016/j.matlet.2016.05.122.

[25] M. Wu, P.R. Munroe, I. Baker, Martensitic phase transformation in a f.c.c./B2 FeNiMnAl alloy, J. Mater. Sci. 51 (2016) 7831-. http://dx.doi.org/10.1007/ s10853-016-0015-4.

[26] O.D. Sherby, J. Wadsworth, D.R. Lesuer, C.K. Syn, The c/a ratio in quenched Fe-C and Fe-N steels - a heuristic story, Mater. Sci. Forum Trans. Tech. Publ. (2007) $215-$.

[27] I. Baker, Hard sphere modeling of the effect of slip on interstitial sites in the B2 structure, J. Mater. Res. 8 (1993) 1203-.

[28] R.W. Cahn, P. Haasen, Physical Metallurgy (Fourth, Revised and Enhanced Edition), North-Holland, Oxford, 1996. http://dx.doi.org/10.1016/B978044489875-3/50033-8.

[29] F. Meng, I. Baker, Nitriding of a high entropy FeNiMnAlCr alloy, J. Alloy. Compd. 645 (2015) 376-. http://dx.doi.org/10.1016/j.jallcom.2015.05.021.

[30] Z. Wu, H. Bei, G.M. Pharr, E.P. George, Temperature dependence of the mechanical properties of equiatomic solid solution alloys with face-centered cubic crystal structures, Acta Mater. 81 (2014) 428-. http://dx.doi.org/10.1016/j.actamat.2014.08.026.

[31] E.O. Hall, The deformation and ageing of mild steel: III discussion of results, Proc Phys. Soc. Sect. B 64 (1951) 747-. http://dx.doi.org/10.1088/0370-1301/64/9/ 303.

[32] N.J. Petch, The cleavage strength of polycrystals, J. Iron Steel Inst. 74 (1953) 25-.

[33] T.H. Courtney, Mechanical Behavior of Materials, McGraw-Hill, New York, 1990.

[34] I. Baker, F. Meng, Lamellar coarsening in $\mathrm{Fe}_{28} \mathrm{Ni}_{18} \mathrm{Mn}_{33} \mathrm{Al}_{21}$ and its influence on room temperature tensile behavior, Acta Mater. 95 (2015) 124-. http://dx.doi.org/ 10.1016/j.actamat 2015.05.006.

[35] K. Lu, L. Lu, S. Suresh, Strengthening materials by engineering coherent internal boundaries at the nanoscale, Science 324 (2009) 349-. http://dx.doi.org/10.1126/ science.1159610 (80-.).

[36] J.D. Yoo, K.-T. Park, Microband-induced plasticity in a high $\mathrm{Mn}-\mathrm{Al}-\mathrm{C}$ light steel, Mater. Sci. Eng. A 496 (2008) 417-. http://dx.doi.org/10.1016/ j.msea.2008.05.042.

[37] J.D. Yoo, S.W. Hwang, K.-T. Park, Origin of extended tensile ductility of a Fe28Mn-10Al-1C steel, Metall. Mater. Trans. A 40 (2009) 1520-. http://dx.doi.org/ 10.1007/s11661-009-9862-9.

[38] Z. Wang, I. Baker, W. Guo, J.D. Poplawsky, The effect of carbon on the microstructures, mechanical properties, and deformation mechanisms of thermomechanically treated $\mathrm{Fe}_{40.4} \mathrm{Ni}_{11.3} \mathrm{Mn}_{34.8} \mathrm{Al}_{7.5} \mathrm{Cr}_{6}$ high entropy alloys, Acta Mater. 126 (2017) 346-. http://dx.doi.org/10.1016/j.actamat.2016.12.074. 